\title{
非切除非小細胞肺癌の放射線治療後の 長期少量化学免疫療法
}

\section{Tegafur + OK-432併用のretrospective study}

\author{
Long-term Mild Chemoimmunotherapy after Radiotherapy \\ for Non-resectable Non-small Cell Lung Cancer.
}

川村暢子・神宮賢一・真琴 ·大曲淳一・増田康治

\begin{abstract}
要旨：1979年から1986年までに九州大学放射線科で放射線治療を受けた非切除非小細胞肺癌患 者のうち, 大学病院で経過が追えた 38 名について, Tegafur·OK-432・PSKの長期少量化 学免疫療法の評価を行った. 生存期間に関するいくつかの因子で補正した後でも TegafurとOK-432を使ったものは有意に生存期間が長くこれらの長期少量投与は延命 に有効である事が示唆された。今後更に無作為比較試験で症例を重ねて効果を確認する 必要があると思われた。
\end{abstract}

〔肺癌 $30(6) ： 903 \sim 911 ， 1990 〕$

Key words : Non-small cell lung cancer, Radiotherapy,

Long term mild chemo-immunotherapy

\section{はじめに}

肺癌はもっとも予後の悪い癌の一つである。 その罹患率の高いこと，近年急増していること などからも治療成績の向上が強く望まれている. ところが, 肺癌は診断された時点で進行癌であ ることが多く，また手術は侵襲が大きいことな どから切除不能の肺癌が全体の半分以上を占め るために, ことに切除不能の肺癌の治療成績の 向上は大きな問題である. 放射線治療は切除不 能肺癌に対するもっとも強力な局所療法であり， 遠隔転移の認められない患者に対しては根治を 目的として放射線照射が行われる。しかし我乃 も報告したように放射線治療の成績は決して芳 しいものではない(1)7).

九州大学放射線科では, 退院後外来で Tegafur, OK-432, PSKの長期投与を行ってき

九州大学放射線科
た。これまでに免疫療法郕の長期投与により進 行肺癌の生存期間の延長が得られたという報告 はあるが8) 11)対象者数が十分ではない。また長 期の化学療法の効果については, 巳らに報告が 少なく, 内田ら ${ }^{12)}$ と著者の一人 ${ }^{13)}$ が報告したの みであり, 長期少量化学免疫療法の肺癌への効 果はまだ確立されたものではない。

そこで, 九州大学放射線科での外来での長期 少量化学免疫療法を評価し, 今後の研究の手が かりを得るのがこの論文の目的である.

\section{対象と方法}

1979年から1986年までに九州大学医学部付属 病院に入院して放射線治療を行った原発非小細 胞肺癌患者 (組織診, 細胞診で猃断され, 外科的 切除を行っておらず, 原発巣に30Gy以上の照射 を受けた患者)は162名であった。このうち初回 
治療の際の死亡退院を除き最終経過観察日まで 九大病院で経過が追えたもの38名を長期少量化 学免疫療法の評価の対象とした(以下対象者と 呼ぶ).死亡退院ではないが対象者とならなかっ たもの(以下非対象者と呼ぶ) は，退院後最終経 過観察日までに他の病院で経過観察となったも のであり86名であった。対象者は死亡退院を除 いた全体の約 $30 \%$ であった。

長期少量化学免疫療法の評価のために，まず 単変量で生存期間に影響のある因子を見つけた. そののち, Coxの比例ハザードモデルにより補 正を行って化学免疫療法剤の効果を判定した.

初回治療の際の診断, 治療に関する詳細は先 の報告7に述べている. 主な点のみ以下に述べ る.

病期分類は1987年UICC TNM分類によった. 入院中の放射線治療は, 原発巣, 肺門, 縦隔 を十分に含む照射野で，6MVのX線で一回150 $\mathrm{cGy}$, 週 5 回, 総線量60Gyを目標として行われ た. 放射線治療の評価のために, 原発巣に $55 \mathrm{~Gy}$ 以上, 縦隔に $40 \mathrm{~Gy}$ 以上の照射が行われたものを 根治的照射が行われた症例とした。 入院中の化 学療法は多剂併用のものだけを評価した。使用 された薬剂は，入院科，時期により異なるが代 表的なものはMitomycin C (MMC) • 5-Fluorouracil $(5-\mathrm{Fu}) \cdot$ Cytosine arabinoside (AraC), Bleomycin(BLM) - Cyclophosphamide $(\mathrm{CPM}) \cdot$ Methotrexate $(\mathrm{MTX})$, Cisplatine $(\mathrm{CDDP}) \cdot$ Adriamycin $(\mathrm{ADR}) \cdot$ Pepleomycin
Fig. 1. Administration of Tegafur, OK-432 and PSK.

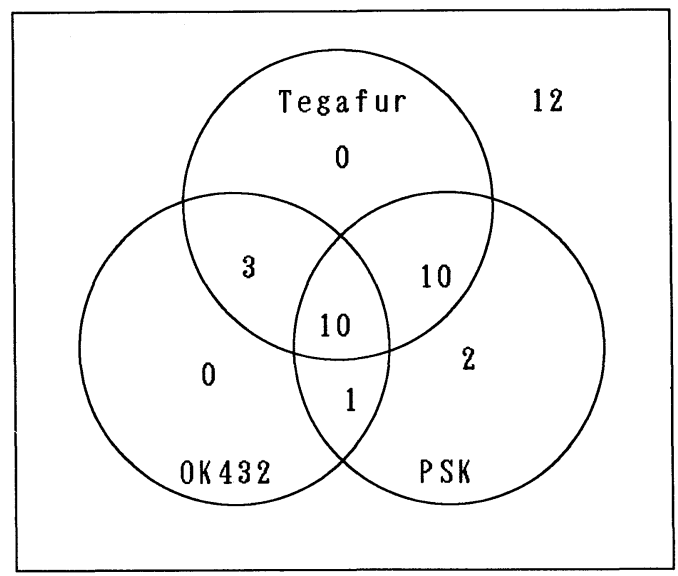

(Pep)であった.

外来での少量化学免疫療法はTegafur 600 $\mathrm{mg}$ (毎日経口または座薬), OK-432 5KE ( 2 週 間に一度皮内注射), PSK $3 \mathrm{~g}$ (每日経口) で行っ た。これらの薬剤の併用に関する状況はFig. 1 に示す通りである。OK-432を使用したものは 14名いたが, そのうち 1 名を除く全員が Tegafurを使用していた。 Tegafurを使用した ものは23名いたが, そのうち $\mathrm{OK}-432$ を使用し ていたものが13名，使用していなかったものが 10名であった. Tegafur, OK-432, PSKを単独 で使っているものはそれぞれ $0,0 ， 2$ 名であ った。また， 3 剤のいずれも使っていないもの (対症療法剂, あるいは抗生物質などだけを投

Table 1. Comparison of characteristics between subject and controls.

\begin{tabular}{llcccc}
\hline Factor & \multicolumn{1}{c}{ Category } & $\begin{array}{c}\text { Subjects } \\
(\mathrm{N}=38)\end{array}$ & $\begin{array}{c}\text { Others } \\
(\mathrm{N}=86)\end{array}$ & $\begin{array}{c}\mathrm{x}^{2} \\
\text { statistics }\end{array}$ & $\begin{array}{c}\mathrm{p} \\
\text { value }\end{array}$ \\
\hline Sex & Male & 31 & 71 & 0.017 & 0.895 \\
& Female & 7 & 15 & & \\
Age & $40-49$ & 5 & 4 & 5.788 & 0.216 \\
& $50-59$ & 10 & 14 & & \\
& $60-69$ & 11 & 33 & & \\
& $70-79$ & 10 & 32 & & \\
& $80-89$ & 2 & 3 & & \\
Method of & Cytology & 19 & 57 & 2.944 & $0.086 \S$ \\
pathological & Histology & 19 & 29 & & \\
diagnosis & & & & &
\end{tabular}




\begin{tabular}{|c|c|c|c|c|c|}
\hline \multirow{5}{*}{$\begin{array}{l}\text { Pathological } \\
\text { classification }\end{array}$} & Squamous cell ca. & 15 & 46 & 6.262 & 0.180 \\
\hline & Adeno ca. & 12 & 26 & & \\
\hline & Large cell ca. & 7 & 7 & & \\
\hline & Adenosquamous cell ca. & 1 & 1 & & \\
\hline & (Not done & 3 & 6) & & \\
\hline \multirow[t]{3}{*}{ Diffentiation } & Highly or moderately & 7 & 13 & 0.000 & 0.993 \\
\hline & $\begin{array}{l}\text { Poorly or } \\
\text { undifferentiated }\end{array}$ & 15 & 28 & & \\
\hline & (Not done & 16 & 45) & & \\
\hline \multirow[t]{4}{*}{ T-factor } & $\mathrm{T} 1$ & 1 & 5 & 2.406 & 0.493 \\
\hline & $\mathrm{T} 2$ & 23 & 47 & & \\
\hline & $\mathrm{T} 3$ & 3 & 14 & & \\
\hline & $\mathrm{T} 4$ & 11 & 20 & & \\
\hline \multirow[t]{4}{*}{$\mathrm{N}$-factor } & N0 & 3 & 19 & 7.923 & $0.048^{*}$ \\
\hline & N1 & 5 & 15 & & \\
\hline & $\mathrm{N} 2$ & 28 & 41 & & \\
\hline & N3 & 2 & 11 & & \\
\hline \multirow[t]{2}{*}{ M-factor } & M0 & 33 & 64 & 2.388 & 0.122 \\
\hline & M1 & 5 & 22 & & \\
\hline \multirow[t]{5}{*}{ Stage } & I & 1 & 11 & 7.054 & 0.133 \\
\hline & II & 2 & 5 & & \\
\hline & III A & 18 & 27 & & \\
\hline & III $\mathrm{B}$ & 12 & 21 & & \\
\hline & IV & 5 & 22 & & \\
\hline \multirow[t]{2}{*}{ Radiotherapy } & Curative irradiation & 30 & 54 & 3.148 & $0.076 \S$ \\
\hline & $\begin{array}{l}\text { Non-curative } \\
\text { irradiation }\end{array}$ & 8 & 32 & & \\
\hline Chemotherapy & Given & 17 & 17 & 8.257 & $0.004^{*}$ \\
\hline \multirow[t]{3}{*}{ Symptom } & Not given & 21 & 69 & & \\
\hline & Present & 32 & 66 & 0.887 & 0.346 \\
\hline & Adsent & 6 & 20 & & \\
\hline \multirow{4}{*}{$\begin{array}{l}\text { Performance } \\
\text { status }\end{array}$} & $100-80$ & 29 & 53 & 3.171 & 0.205 \\
\hline & $70-50$ & 8 & 27 & & \\
\hline & $40-0$ & 0 & 3 & & \\
\hline & (unkown & 1 & 3) & & \\
\hline \multirow{4}{*}{$\begin{array}{l}\text { Improvement } \\
\text { of symptoms }\end{array}$} & Marked improvement & 11 & 26 & 0.776 & 0.678 \\
\hline & Slight improvement & 17 & 35 & & \\
\hline & Worsening & 4 & 5 & & \\
\hline & $\begin{array}{c}\text { (Inappropriate for } \\
\text { evaluation) }\end{array}$ & 6 & 20 & & \\
\hline \multirow{3}{*}{$\begin{array}{l}\text { Improvement of } \\
\text { radiological } \\
\text { findings }\end{array}$} & Marked improvement & 28 & 63 & 0.003 & 0.998 \\
\hline & Slight improvemnt & 7 & 16 & & \\
\hline & Worsening & 3 & 7 & & \\
\hline \multirow[t]{3}{*}{ Outcome } & Death by lung cancer & 34 & 76 & 5.409 & 0.144 \\
\hline & Death by other causes & 0 & 7 & & \\
\hline & Alive & 4 & 3 & & \\
\hline
\end{tabular}


与)は12名であった。それぞれの使用期間は, Tegafurについては 1 力月から 23 力月 (平均值 13力月, 中央值 10 力), $\mathrm{OK}-432$ につては 4 力月から 32 力月 (平均値 17 力, 中央值 17 力), PSKについては 1 カ月から 32 力 (平均値 12 力 月，中央值 8 力) であった. 使用期間と外来観 察期間を比べるとTegafurでは23名中20名が, OK-432については14名中12名が，PSKについ ては23名中 21 名が半分以上の期間に使用されて いた。途中で投与を中止したもののうち一名は TegafurとOK-432を投与されていたが, 治療後 18カ月以上して経過良好のため中止して現在も 生存中である。この症例以外で投与が中止され 理由は, 全身状態の悪化と肝機能障害であった。 今回の対象症例では, 投与中の副作用は特に認 められなかった。

ただし, 入院中の化学療法, 外来での少量化 学免疫療法の有無は治療医の判断によっており, 必ずしも無作為に行われたものではなかった。

経過観察は1988年10月31日まで行った。

生存率はKaplan-Meier法により計算し，検 定はlogrank testによった。関連性の指標とし ては $\chi 2$ 検定を用いた。長期少量化学免疫療法の 効果判定に際しては他の因子による補正が必要 なのでCoxの比例ハザードモデルを用いた。ま たこれらの計算はパッケージプログラムの SAS (Statistical Analysis System)で行った.

\section{結 果}

\section{1) 対象者と非対象者の比較}

対象者が偏った集団である可能性があるので, 対象者と非対象者を背景因子, 生存率から比較 した。

背景因子の分布についてはTable 1に示した. $\chi^{2}$ の値が0.05より小さかったのはN因子・化 学療法の有無で, $\mathrm{p}$ 值が 0.05 と 1 の間であった のは病理診断の方法・放射線治療の内容であっ た.これらから，対象者は非対象者にくらべて， 検查, 治療とも十分に行われており, 病期では N2 STAGEIII A症例の割合が多かった.

対象者, 非対象者の生存率についてはFig. 2 に示した。対象者全体の50\%生存期間 (Median
Fig. 2. Comparison of survival between subjects and controls.

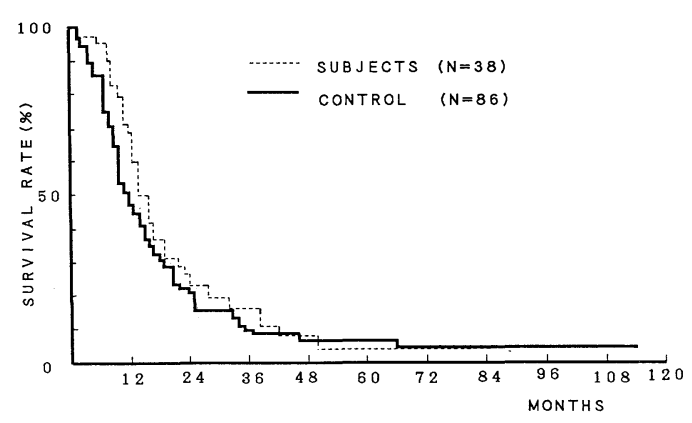

survival time；以下MSTと略す)は 14 力月，1 年生存率は $68.4 \%, 3$ 年生存率は $15.6 \%, 5$ 年 生存率は $3.4 \%$ であり, 非対象者全体のMSTは 13 力月, 1 年生存率は $51.1 \%, 3$ 年生存率は 10.2 $\%, 5$ 年生存率は $7.0 \%$ であった. 対象者と非対 象者の差は有意ではないが, 対象者の方が治療 後短期間では予後の良い傾向があった。

2 ）予後修飾因子の分析

対象者における各変数についての分布, 変数 内のカテゴリ一別のMST, logrank testのp値 をTable 2に示した. pの值が 0.05 よりさいの は性, 遠隔転移の有無, 入院中の化学療法の有 無, Tegafurの使用の有無, OK-432の使用の有 無であった。また放射線治療の内容についての p值は0.0798であった。これらから女性より男 性，M1より M0，入院中の化学療法なしよりあ ク，Tegafur使用なしよりあり，OK-432使用な しょりあり，非根治的照射より根治的照射で有 意に生存期間が長かった。

\section{3) 長期少量化学免疫療法の評価}

少量化学免疫療法で使用された薬剂のうち Tegafur, OK-432が生存期間に強い影響を及ぼ していたので, 少量化学免疫療法の評価はこの 二つについて行った。薬剤の併用が多く行われ ているために個々の薬剤の効果の評価は困難と 考之られたので, 長期少量化学免疫療法に関す る変数としてTegafurとOK-432の両方を使っ た群(13名), どちらか一方を使った群(11名), どちらも使わない群(14名)に分けた。

まず，この 3 群についてのKaplan-Meier法 
Table 2. Comparison of prognosis between categories and each factor.

\begin{tabular}{|c|c|c|c|c|c|}
\hline Factor & $\begin{array}{c}\text { Total } \\
\text { number }\end{array}$ & Category & number & MST & $\begin{array}{c}\mathrm{p} \text {-value in } \\
\text { logrank test }\end{array}$ \\
\hline \multirow{2}{*}{ Sex } & \multirow[t]{2}{*}{38} & Male & 31 & 17 & \multirow[t]{2}{*}{$0.0082^{*}$} \\
\hline & & Female & 7 & 11 & \\
\hline \multirow[t]{2}{*}{ Age } & \multirow[t]{2}{*}{38} & Under 70 & 26 & 14 & \multirow[t]{2}{*}{0.7143} \\
\hline & & Over 70 & 12 & 17 & \\
\hline \multirow{4}{*}{$\begin{array}{l}\text { Pathological } \\
\text { classification }\end{array}$} & \multirow[t]{4}{*}{35} & Squamous cell & 15 & 14 & \multirow[t]{4}{*}{0.8721} \\
\hline & & Adeno & 12 & 16 & \\
\hline & & Large cell & 7 & 13 & \\
\hline & & Adenosquamous cell & 1 & 19 & \\
\hline \multirow[t]{4}{*}{$\mathrm{T}$ factor } & \multirow[t]{4}{*}{38} & $\mathrm{~T} 1$ & 1 & 17 & \multirow[t]{4}{*}{0.1231} \\
\hline & & $\mathrm{T} 2$ & 23 & 14 & \\
\hline & & T3 & 3 & 19 & \\
\hline & & $\mathrm{T} 4$ & 11 & 24 & \\
\hline \multirow[t]{4}{*}{$\mathrm{N}$ factor } & \multirow[t]{4}{*}{38} & N0 & 3 & 85 & \multirow[t]{4}{*}{0.1331} \\
\hline & & N1 & 5 & 13 & \\
\hline & & $\mathrm{N} 2$ & 28 & 14 & \\
\hline & & N3 & 2 & 14 & \\
\hline \multirow[t]{2}{*}{ M factor } & \multirow[t]{2}{*}{38} & M0 & 33 & 16 & \multirow[t]{2}{*}{$0.0036^{*}$} \\
\hline & & M1 & 5 & 10 & \\
\hline \multirow[t]{5}{*}{ Stage } & \multirow[t]{5}{*}{38} & Stage I & 1 & 17 & \multirow[t]{5}{*}{$0.0072^{*}$} \\
\hline & & Stage II & 2 & 12 & \\
\hline & & Stage IIIA & 18 & 16 & \\
\hline & & Stage IIIB & 12 & 24 & \\
\hline & & Stage IV & 5 & 8 & \\
\hline \multirow{2}{*}{ Symptom } & \multirow[t]{2}{*}{38} & Present & 32 & 14 & \multirow[t]{2}{*}{0.4104} \\
\hline & & Absent & 6 & 14 & \\
\hline Performance & 37 & $100-80$ & 29 & 16 & 0.2065 \\
\hline status & & $70-50$ & 8 & 10 & \\
\hline Radiotherapy & 38 & Curative irradiation & 30 & 16 & $0.0798 \S$ \\
\hline & & Non-curative irradiation & 8 & 14 & \\
\hline Chemotherapy & 38 & Given & 17 & 16 & $0.3749^{*}$ \\
\hline & & Not given & 21 & 14 & \\
\hline Improvement of & 33 & Marked improvement & 11 & 10 & \\
\hline symptoms & & Slight improvement & 18 & 16 & \\
\hline & & Worsening & 4 & 23 & \\
\hline Improvement of & 38 & Marked improvement & 28 & 14 & 0.9084 \\
\hline radiological & & Slight improvement & 7 & 16 & \\
\hline findings & & Worsening & 3 & 16 & \\
\hline Tegafur & 38 & Given & 23 & 19 & $0.0078^{*}$ \\
\hline & & Not given & 15 & 11 & \\
\hline OK-432 & 38 & Given & 14 & 28 & $0.0014^{*}$ \\
\hline & & Not given & 24 & 13 & \\
\hline PSK & 38 & Givèn & 23 & 19 & 0.2621 \\
\hline & & Not given & 15 & 13 & \\
\hline
\end{tabular}


による累積生存率のグラフをFig. 3に示した. 両方とも使った群, ぞちらか一方を使った群, どちらも使わない群の median survivalは, それ ぞれ28力月，16力月，11.5力月であった。また 一年生存率はそれぞれ $92.3 \% ， 72.7 \% ， 42.5 \%$, 二年生存率はそれぞれ $60.6 \%, 0 \%, 7.1 \%$ であ った。

少量化学免疫療法を多変量解析で評価する際, 補正する因子として，今回の解析で生存期間に 影響を及ばしていることがわかった性，M因子， 放射線療法の内容, 化学療法の有無だけでなく, 今回の結果では生存期間に有意な影響を及ぼし ていないが前回の報告7中の予後因子であった PS，N因子を加えた。つまり，目的変数を生存 期間, 説明変数を性, N因子, M因子, 放射線療 法の内容, 化学療法の有無, PS, 長期少量化学 免疫療法の内容とし, Coxのproportional hazard modelを使って計算を行った (Table 3 ).

長期少量化学免疫療法でTegafurとOK-432 の両方を使った群はいずれも使わなかった群と 比べると，リスク比は0.249(95\%信頼区間 0.0773-0.801）と有意に小さくなり,どちらかだ けを使った群はいずれも使わなかった群と比べ るとリスク比は $1.00(0.349-2.89)$ となり有意差 はなかった。また，長期少量化学免疫療法に関 する変数としてOK-432とTegafurを使い,他は 同じ変数で補正を行うと， $\beta$ の值はそれぞれ -1.073 と -0.716 , 標準誤差は0.551と0.512(95 \%信頼区間は0.115-1.008と0.179-1.332), p值
Fig. 3. Cumulative survival rate by administration of Tegafur, OK-432, PSK.

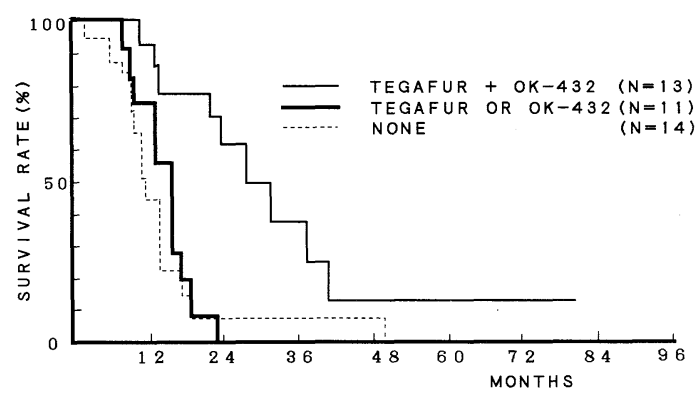

は0.0517と0.1619となり，ともに有意ではない がOK432の方がp值が小さく, 予後に有利な傾 向があった。

\section{考 察}

1) 対象者と非対象者の比較

今回の検討の対象者は, 非切除非小細胞肺癌 で初回治療を生存退院した124名中, 最後まで九 州大学で経過が観察できた38名とした。このよ うに限定したのは次のような理由による。対象 者を生存退院したもの全体にすれば, 状態が悪 いため大学病院に来れないものなどが化学免疫 療法非施行群となる可能性がある。そうすると これらのものの生存期間が短いことは当然であ $\eta$, 化学免疫療法を過大評価することとなろう. また，薬剤の投与期間を考えると，ごく短期間 のみ大学病院に来て薬剂の投与を受け, その後

Table 3. Multivariate analysis using Cox's proportional hazard model.

\begin{tabular}{|c|c|c|c|c|}
\hline Factor & $\beta$ & $\begin{array}{l}\text { standard } \\
\text { error }\end{array}$ & p-value & risk ratio \\
\hline Sex (Male:1, Female:2) & 0.6140 & 0.6181 & 0.3205 & 1.848 \\
\hline $\begin{array}{l}\mathrm{N} \text {-factor } \\
\quad(\mathrm{N} 0: 0, \mathrm{~N} 1: 1, \mathrm{~N} 2: 2, \mathrm{~N} 3: 3)\end{array}$ & 0.5621 & 0.3302 & $0.0887 \S$ & 1.754 \\
\hline M-factor (M0:,1 M1:2) & 1.329 & 0.8600 & 0.1223 & 3.777 \\
\hline $\begin{array}{l}\text { Radiotherapy } \\
\quad \text { (Curative:1, Non-curative:2) }\end{array}$ & -0.5356 & 0.5939 & 0.3671 & 0.5853 \\
\hline $\begin{array}{l}\text { Chemotherapy } \\
\text { (Performed:1, Not performed:2) }\end{array}$ & 0.2018 & 0.4679 & 0.6663 & 1.224 \\
\hline $\begin{array}{l}\text { Long-term therapy } \\
\text { (Tegafur and OK432:2, others:1) }\end{array}$ & -1.391 & 0.5967 & $0.0198^{*}$ & 0.2488 \\
\hline $\begin{array}{l}\text { Long-term therapy } \\
\text { (Tegafur or OK432:2, others:1) }\end{array}$ & 0.00425 & 0.5397 & 0.9937 & 1.004 \\
\hline
\end{tabular}


他院で経過を追うことになったものを施行群に 含めれば，化学免疫療法を過小評価する事にな る.さらに, 身体的に同じ状態でも大学病院で 経過観察を希望するものとそうでないものでは, 社会的, 経済的状況や病気に対する態度が異な り，生存期間に関係することも考之られる ${ }^{14)}$.

事実, 背景因子からみると (Table 1) 対象者の 方が，十分な検查，治療を受けた割合が多く，

N2 stageIIIAのものが多かった.

生存率からみると, 対象者の方が, 差は有意 ではないものの特に治療終了後短い期間では良 い傾向にあった(Fig. 2). 非対象者の中にも途 中まで化学免疫療法剤を投与されていたものも いることから, この生存期間の差は, 単に対象 者中に化学免疫療法剤の投与を受けていたもの が含まれていたためではなく，背景因子の違い にもよると考之られる，以上の二つの点より対 象者と非対象者は異なる特性を持った集団であ ると推察された。

対象者が38名と少なく, 今回の結論から非切 除非小細胞癌全体について類推する事は無理が あろう。とはい之，今回の対象者中比較的大き な割合を占めた N2 stage IIIA症例は放射線治 療のもっともよい適応であり，この病期の症例 を多く含み十分な放射線照射, 化学療法を施行 された症例が多い集団では, 今回の結果の普遍 化は容易であると考えられる。

\section{2 ) 予後因子について}

非切除非小細胞癌全体162名において生存期 間に大きな影響を与える予後因子はPS, N因 子, 放射線治療の内容であった ${ }^{71}$. 今回の対象者 38名のなかでは, PSは大きな意義は持たなかっ た。これは，PSの悪い症例の多くは死亡退院し ており，対象者となったものは比較的PSの良い ものが多かったためであろう。N因子の対象者 中での分布は著しく偏っているために, 単変量 ではN因子内での差は有意とはならなかった。 放射線治療の内容は, 今回の対象者中でも生存 期間への影響が考えられた。逆に今回生存期間 に大きな影響を与えた因子のうち, 性・M因子・ 化学療法は先の報告では予後に大きな影響を与 える因子とはなっていない.このように予後因
子は対象者の背景因子の違いで異なることは当 然であり，対象者の性格を把握することはこの ことからも必要と考えられる。

\section{3) 長期少量化学免疫療法の評価}

OK-432, Tegafur, PSKの三者の有効性につ いて検討した。それぞれの薬剤は無作為に投与 の有無を決奴ものではなく, さらに併用 のいろいろな組み合わせがおこなわれていたた めそれぞれの薬剤の効果の評価は困難であった. これまでにPSKの肺癌に対する有効性を報告 した文献は見あたらないが,この研究でもPSK は生存期間を延長するとはいえなかった。単変 量でみて生存期間との関連の大きかったのは TegafurとOK-432のみであった.

OK-432の効果については, 進行肺癌を対象 とした先の報告8) 11)と一致している.

この二つの薬剤について, 両方を使用した群, 片方だけを使用した群，どちらも使用しない群 にわけて検討した。生存期間に関連する他の変 数で補正した結果, 両方を使用した群のみが有 意に生存期間がよく，片方だけを使用した群で は生存期間の改善は有意ではなかった。このこ とは5-FuとOK-432とを併用した内田ら ${ }^{12)}$ の結 果と一致していた。

OK-432とTegafurをそれぞれ別に，他の変数 で補正して計算するとOK-432の方が上記の結 果に近いものの, OK-432単独よりはOK-432+ Tegafurの方がさらに生存期間の改善は有意で あった。この結果から $\mathrm{OK}-432$ が最も延命に有 用であったと考えられた.また, Tegafurを併用 することにより相乗的な効果が示唆されたが, その理由について検討する十分な資料はない。

今回の結果は対象者数が少なく, 無作為比較 試験による結果ではないという欠点はあるが, 生存期間に影響を与える他の因子を考慮した解 析であり, OK-432, Tegafurの少量長期投与の 有効性を支持する根拠となると考えられた。今 後は, OK-432 と Tegafurの相乗効果の有無を含 めて, 無作為比較試験により症例を重ねて長期 少量化学免疫療法の効果を確認すべきと考えら れる。 
文 献

1）日本TNM分類がん委員会国立がんセンタ

1982. 一：全国肺がん患者登録(第 7 報)。45頁， 1988.

2) 片岡正明, 河村 正, 木村 誠, 他：非切除肺 癌の放射線治療成績の検討. 日本医放会誌, 48:717-726, 1988.

3) Coy, P., Kennelly, G.M. : The role of curative radiotherapy in the treatment of lung cancer. Cancer, 45:698-702, 1980.

4）木村 誠, 中島信明, 早川和重, 他：原発性肺 癌の放射線治療成績向上に関する検討。日癌 治, 18：1821-1830, 1983.

5) Lanzotti, V.J., Thomas, D.R., Boyle, L.E. et al. : Survival with inoperable lung cancer. Cancer, $39:$ 303-313, 1979.

6) Petrovich, Z., Stanley, K., Cox, J.D. et al. : Radiotherapy in the management of locally advanced lung cancer of all cell types. Cancer, 48 : 1335-1340, 1981.

7）川村暢子：非切除, 非小細胞癌の放射線治療に 招ける予後因子。日放腫会誌，2：101-110, 1990.

8）小川恭弘，木村修治，今城吉成，他：III， IV 期 肺癌の放射線治療を軸とした非観血的療法に おける免疫療法併用の臨床的意義一特にOK432を中心に一。日癌治, $17: 1949-1956$,

9) Watanabe, Y., Iwa, T. : Immunotherapy of lung cancer : A randomized clinical trial of OK-432 immunotherapy and a review of the literature on nonspecific immunotherapy. Int. J. Immunotherapy, 2: 51-67, 1986.

10）渡辺洋宇：肺癌治療における $\mathrm{OK}-432$ 免疫療法 併用の効果一無作為比較試験での検討一. Excerpta Medica. 橋本嘉幸, 野本亀久雄, 服部孝 雄，他監修，東京，P108-119， 1986.

11) Kimura, I., Ohnoshi, T., Yasuhara, S. et al. : Immunochemotherapy in human lung cancer using the streptococcal agent $\mathrm{OK}-432$. Cancer, $37: 2201-2203,1976$.

12) Uchida, A., Hoshio, T. : Clinical studies on cell-mediated immunity in patients with malignant disease. Cancer, 45:476-483, 1980.

13）神宮賢一, 松井正典, 松浦啓一他：肺癌推持療 法に於けるFT207の効果の検討。肺癌20 (supple) : 102, 1980.

14) Stavraky, J.E., Jubcade, J.E., Stewart, M.A. et al. : The effect of socioeconomic factors on the early prognosis of cancer. J. Chornic Dis., 40 : 237-244, 1987.

(原稿受付 1989 年12月 26 日 / 採択 1990 年 5 月 1 日) 


\title{
Long-term Mild Chemoimmunotherapy after Radiotherapy for Non-resectable Non-smll Cell Lung Cancer.
}

\author{
Nobuko Kawamura, Kennichi Jingu, Makoto Miyoshi \\ Junnichi Ohmagari and Koji Masuda \\ Department of Radiology, Faculty of Medicine, \\ Kyushu University
}

\begin{abstract}
We evaluated long-term administration of Tegafur, OK-432 and PSK after radiotherapy for non-resectable non-small cell lung cancer.

In our hospital 162 patients received radiotherapy between 1979 and 1986. Among those who were discharged after the first admission, 38 were completey followed up by us and 86 were not. These two groups were somewhat different in regard to patient characteristics and survival times.

In the former group, we examined the effect of long-term mild chemoimmunotherapy by multivariate analysis using Cox's proportional hazard model. This revealed that those who were given Tegafur and $\mathrm{OK}-432$ showed better prognosis even after adjustment for several factors.
\end{abstract}

